\title{
THE BOOKNESS OF A BOOK
}

\section{Ramón C. Sunico}

\section{About the Author}

Ramón C. Sunico is a bilingual writer, book designer, book project manager, editor and teacher. In Augsburg, Germany, he designed, printed, and bound his first book of poetry, The Secret of Graphite: Poems in Two Tongues (1989), the first book to do away with the artificial segregation of English from Filipino poems. As manager of Cacho Publishing House, he was the first to publish a line of picture books with parallel, bilingual texts, now common practice among publishers. Included in the line was Two Friends, One World/ Mata at Mangga, both winners of the first children's story competition of the Carlos Palanca Memorial Awards. He was similarly the first to moderate a locally-based listserv (the precursor of e-groups) on Philippine arts and letters, rp-books. Similarly themed listservs were based in the US and Australia. He also belonged to the pioneering group that used early desktop computers to design Philippine literary titles during the flowering of local book publishing after the ouster of Marcos. 
Among all the species of literature, the page of a book is most congenial to the poem. With its stanzas and shorter line, the spaces that help to shape lyric verse, for example, allow the warmth of paper to glow between poetic lines, engaging both eye and mind, instead of weighing them down with flowing prose. It is the same with a digital book with the monitor's warm whiteness establishing a frame for the delicate structure of the text.

Charlie Samuya Veric's first book of poems, Histories, embodies this happy meeting of mind and matter. The book surprises with its polish and the tight integration of poem and page, the generous use of white space serving as a metaphor for the psychic and emotional spaces one enters into when reading the thirty-five poems. Thirty-five windows. Thirty-five invitations aux voyages.

More and more, contemporary titles of Philippine literature turn to photographic images to use as covers. This book shows why. The front cover contains a Borgesian figure of Asian complexion, an old man in a hat and a black Western suit, looking forward (but also managing to look like he is looking back), sitting calmly with his suitcase on a shallow drafted Burmese canoe, wooden, flat. Above him, towers a pale cloud-streaked sky and the delicate sans serif typeface of the title, separated into three syllables, spread over the page: HIS TOR IES. The back cover appears to be a mirror of the image in front, but with the old man missing.

It is a promise of air and breath, a tall sky and a broad river-again, of the space we need to dream and imagine, to speak-but really to sing. For a first book, this is a pretty slick construction. The ampleness of space continues to the interior of this volume. And the reader is treated to an introduction that is graphically broken up and spread over a succession of pages, to look like parables and aphorisms, even truncated journal entries that intrigue those of today's short attention spans to read further. As with many first books, the book contains a polemic (for that is what all announcements of literary arrival are) with both the now expected ars poetica and a Who-I-Am following the mode of the via negativa.

But it also ensnares the reader with the subtle enchantment of its first "history." And so Histories begins:

A team of art historians and archeologists had unearthed a 16th century Ottoman village on Hungarian soil. The village was "of considerable size," bounded by a ditch that served as a fortification. Beneath the ground, shards of luxury goods such as Chinese porcelain and Persian crystal, speckled what was once a village that housed the invading bulls of the Ottoman Empire-90,ooo strong-who were poised to turn Vienna and the rest of Europe into a souk. 
The introduction continues to tell the story of this village, how it was laid siege to by the forces of Suleiman the Magnificent, how, in later days, it would hide the great sultan's heart:

... Out of this shrine, a village emerged. Out of the village, a tavern and inn.

\{\}

In October of 2013, news came of art historians and archeologists stumbling into a village while searching for the sultan's heart.

\{\}

I, too, am looking for a missing heart.

After that and a quote from Herodotus, the poems follow, divided into three sections opened by the same sans-serif that is both in-your-face large and yet surprisingly delicate as Roman numerals.

Facing them are gritty black and white, verso, full-page photographs of people in the city, taken on the move, capturing both blur and edge, serving as dark anchors that keep the visual airiness from dissipating into nothingness.

It is as all books should be: a book with a look, a plan and so, a reason to be. These were the thoughts in my mind as I cast it about wondering how and where to start this review.

\section{How to Read a Poem}

A student misreads

a poem about losing love

to be about love between a mermaid and a fisherman.

I do not know how it comes to a young man,

learning to read between the lines.

How a poem about love lost could mean

other than its disappearance.

Imagine my surprise then when during the book launch, both the book designer Bolix aka Oliver Ortega (who referenced Marx's XVIIIth Brumaire and its own tip of the hat to Hegel) and the photographer of the images in the book's interior, 
Daniel Roque, were asked to speak about their own involvement in the making of the book. These people are normally invisible in a book, content to let their craft help the reader enjoy the text, happy enough to hide behind the artful emptiness against which letters and words stand out.

It was a happy anomaly, as book launches go, for it validated my sense that the author understood that a book is more than a bound typescript, that it is a social object, a shared vision of people working together, each with their special skill, like a tiny cathedral of paper and board, assembled piece by piece and by countless pairs of nameless hands.

The only person missing at the launch was the cover's photographer, Bettina Flitner (http://www.bettinaflitner.de) from Germany. The photo is the second in her series, Boatpeople. Apparently, the poet and photographer became friends on Facebook and she allowed him to use her image gratis.

Of the poems, other people far better at parsing poetry have written their own reviews. I mention first the poet of prodigious memory, Gémino Abad, and then Joey Baquiran. During the launch, a review of E. San Juan, Jr. was also read but I felt that it was Farida Kabayao's violin performance (Glück and Mendelssohn) that captured the mood of the book, proving once again the old saw that, of all the musical instruments, it is the violin, when well played, that closest comes to the human voice.

And this is what lies at the heart of the book. Weaving through the elegant and essential armature of picture, typeface, and layout is the poet's voice-speaking from far away or from the cold comfort of a bed, telling one of those curious stories one picks up from history books or a fragment of that one story that is one's life.

There are clouds and rivers in that voice, the grainy rectangles of a cityscape and the salty call of a port, too. It is a voice populated by various personalities, Clytemnestra and Agamemnon, Neruda and Cavafy, to name a few.

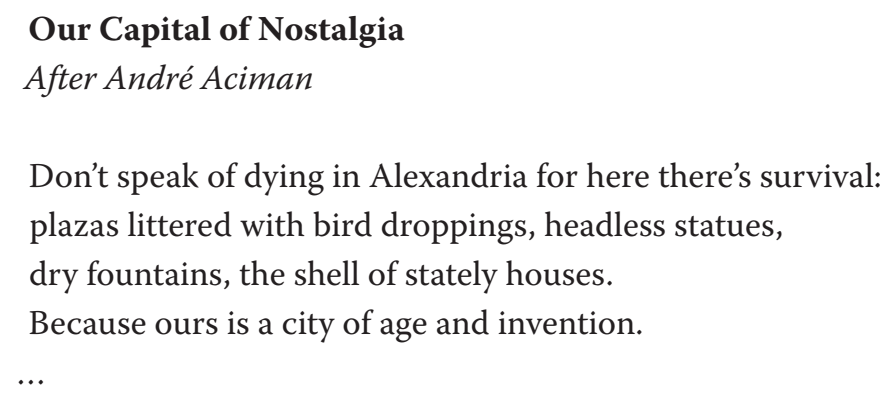




\section{Neruda in India}

He lost his heart to a native girl

known as Josie Bliss on the Hindu streets

of colonial India. She whom he loved

truly, deeply, shed the dazzling sarong

in the darkness of her room for him

to see. There, he came to know

her secret Burmese name. What

it was, we shall never learn.

And yet one never quite loses the compass of the poet's voice that remains rooted in his family from Aklan and draws sustenance from such memories as can be found in the darknesses of a rented room or the sun-washed corridor in a former school that frames the shuffle of an aging philosophy teacher.

This is a thin book but it is heavy with both purpose and poetry. It has pictures and delicious open spaces. But most of all, it sings. 